\title{
A Child AT Risk \\ The Czech RePublic EXPERIENCE
}

\section{Zdeňka Králíčková ${ }^{1}$}

\section{Faculty of Law, Masaryk University, Brno, Czech Republic email: zdenka.kralickova@law.muni.cz}

KRÁLÍČKOVÁ, Zdeňka. A Child at risk. The Czech Republic experience. International and Comparative Law Review, 2012, Vol. 12., No. 2, pp. 87-100. DOI: 10.1515/iclr-2016-0088.

\begin{abstract}
The paper aims at finding an answer to the question whether abandoning a child or applying for hidden identity makes the way of the child to a substitute family by adoption easier. Further, an attention is paid to surrogate motherhood in connection with the child's rights, including the right of the child to know his/her origin. The final part is focused on protection of the child endangered by domestic violence.
\end{abstract}

Keywords: child, risk, pathologies, abandoning, substitute family, surrogate motherhood, Czech Civil Code

\section{INTRODUCTION}

The annual statistics show that a very high number of children are born out of wedlock in the Czech Republic. ${ }^{2}$ In some cases it is planned, in others it is a failure in life. It is well-known fact that there has been an increase of cases where the child's father is not legally determined before the birth. There are a very high number of fatherless children especially with mothers who have only the basic education, who are on the edge of social exclusion and on the edge of poverty. ${ }^{3}$

Unfortunately, social reasons sometimes lead single mothers to abandoning their children and leaving them in the so-called baby-boxes immediately after birth (for detail see part 1.3.), or to signing an application for hidden birth in hospital under the law (see part 1.2.). The public as well as the experts wonder why

1 Associate Professor, Faculty of Law, Masaryk University, Brno, the Czech Republic.

2 Cf. http://www.czso.cz/eng/redakce.nsf/i/percentage_of_extra_marital_births_1950_2010 (15 ${ }^{\text {th }}$ May 2012). See Attachment No I.

3 Cf. a number of works by Senta Radvanová dealing with the problem of single-parent families and the phenomenon of "feminization of poverty"; Radvanová, S.: Žena a právo [THE WOMAN AND THE LAW]. Praha: Orbis, 1971; Stav české rodiny a rodinného práva v současné době [THE CURRENT STATE OF THE CZECH FAMILY AND FAMILY LAW]. Právní praxe, 1999, No 2 - 3; Vyživovací povinnost s otazníky [THE MAINTENANCE DUTY WITH QUESTION MARKS]. Právo a zákonnost, 1990, No 8. 
women in an advanced country, which the Czech Republic is when compared with other parts of the world, give up their children in relatively high numbers in the early $21^{\text {st }}$ century.

The New Civil Code, which was adopted in the Czech Republic after many peripeties last year (cf. the Act No 89/2012 Coll. effective since 1 January 2014, hereinafter NCC), introduces the term of surrogate motherhood into the Czech legal order (Section 804, NCC). The rights of child are left aside and the fact of uncertain position of child from the very beginning is not taken seriously.

In addition to the low marriage rate the number of divorces paradoxically increases in the Czech Republic. ${ }^{4}$ The statistics reveal that petitioners are mostly women and minors are not an obstacle to a radical termination of the matrimonial bond. ${ }^{5}$ Moreover, divorce is not taken as a stigma but as a dignified solution of a difficult life situation. We may fully agree with the opinion that a minor cannot be protected against the divorce of his/her parents. ${ }^{6}$ Nevertheless, the Act No 94/1963 Coll. on Family (hereinafter AF) includes the so-called "hardship clause" consisting in prohibition of divorce if it were in conflict with the interests of a minor due to special reasons (Section 24, Para 2, AF). The New Civil Code sets this forth in a similar manner (see Section 755, Para 2, Sub-Para b, NCC). An interpretation and mainly an application of this provision are rather difficult. If one of the spouses seeks the divorce and the court finds a qualified breakdown of the relationship between the spouses it is a question whether the court dismissal of the divorce is of a benefit to anyone regarding the interests of the child. This conception may make the situation of the spouse endangered by domestic violence more difficult when his/her priority is safety, separation from the attacker and - a speedy divorce. It is well-known that victims of domestic violence are primarily women and that minors are often witnesses of a pathological behavior. Unfortunately, the phenomenon of domestic violence is not mentioned at all in

4 Cf. http://www.czso.cz/eng/redakce.nsf/i/marriages_and_divorces_1950_2010 (15 ${ }^{\text {th }}$ May 2012). See Attachment No II.

5 It is also a well-known fact that minors are mostly put into the exclusive care of mothers after divorce. Even if this "traditional model" is not supported by the gender-neutral provision of Section 26, AF, the statistics say that this is the most frequent post-divorce arrangement. The courts frequently approve agreements of parents in this "traditional spirit" but they often approach the "traditional arrangement" authoritatively, e.g. when they acknowledge the so-called factual state, or the alternative care is not feasible e.g. because of a longer distance from the new residence of the parents, or - which is much more serious - because the alternative care is refused by the mother. In connection with the regulation care the maintenance duty towards the minors is also obligatory regulated and on a case-by-case basis the "traditional contact" with the so-called non-caring parent. The courts seldom prohibit contact or regulate the so-called assisted contact or the contact on a neutral ground even if there are reasons for that, e.g. domestic violence.

6 Towards this, see Hrušáková, M. a kol.: Zákon o rodině. Zákon o registrovaném partnerství. Komentár [THE ACT ON FAMILY. THE REGISTERED PARTNERSHIP ACT. A COMMENTARY]. $4^{\text {rd }}$ ed. Praha: C. H. Beck, 2009, pp. $71-72$. 
connection with the legal regulation of divorce, neither in the existing law nor in the New Civil Code. Therefore the situation of minors is very difficult due to the silence of the lawgiver.

We hold the view that many cases of pathology - intended motherhood without a father, abandoning children or making their legal position uncertain from the very beginning, instability of co-existence of couples with minors, domestic violence - do not contribute to the desired pro-family conduct and we think that they make the position of children (and their mothers as well as fathers) both actually and legally worse in the Czech Republic.

The following text aims at finding an answer to the question whether abandoning a child or applying for hidden identity makes the way of the child to a substitute family by adoption easier. Further, an attention is paid to surrogate motherhood in connection with the child's rights, including the right of the child to know his/her origin. The final part is focused on protection of the child endangered by domestic violence.

\section{HIDDEN BIRTHS, SO-CALLED BABY-BOXES AND REAL CHANCES OF THE CHILD TO BE ADOPTED}

1.1. First, it is necessary to consider the status conception of motherhood in the Czech Republic. The ancient Roman law principle of mater semper certa est respecting the fact of birth has been traditionally considered as the basis for creating the status relationship of mother - child. This principle was expressly introduced into the Czech legal order only in 1998 by the so-called Great Amendment to Act on Family (see Art. 50a, AF). ${ }^{7}$ However, the principle was respected even when the phenomenon of assisted reproduction appeared and created a disharmony between the biological (genetic) reality, the social situation and the legal status. ${ }^{8}$ Due to a long time passivity of the lawgiver there was an obstacle to the development of the so-called surrogate motherhood on a commercial basis. Nevertheless, the rights of the mother need not be, and frequently are not, identical with the rights of the child.

1.2. As for the principal negative elements of the Czech legal order concerning motherhood it is necessary to point out the Act pursuant to which the single mother older than 18 years with a permanent residence in the Czech Republic has a right to hide her identity in connection with birth (see Act No 422/2004 Coll.).

7 Cf. also Haderka, J.: Otázka mateřství a otcovství od účinnosti zákona č. 91/1998 Sb. [THE QUESTION OF MOTHERHOOD AND PARENTHOOD SINCE THE ACT No 91/1998 COMING INTO EFFECT]. Právní praxe, 1998, No. 9, p. 530 ff.

8 Cf. Sections 27d-27h, Act No 20/1966, Coll. on Care of People's Health as amended by Act No 227/2006 Coll. on Human Embryo and Stem Cell Research and Related Activities and a Change of Some Related Acts. Towards this in detail, see Frinta, O.: Asistovaná reprodukce - nová právní úprava [ASSISTED REPRODUCTION - A NEW LEGAL REGULATION]. Právní fórum, 2007, No. 4, p. 123 ff. 
The Act was adopted at the initiative of members of Parliament in 2004 without going through the standard legislative process. This Act did not change the Act on Family which expressly established the principle of mater semper certa est. The mother is a woman who gave birth to the child (see Art. 50a, AF). The 2004 Act amended without any conception the Act on People's Health, the Act on Records of Births, Name and Surname, and the Act on Public Health Insurance. We should add that the mother is allowed to ask for hiding her identity after giving birth to the child. ${ }^{9}$

The experts came to the conclusion that the child, whose mother wants her personal data not to be revealed at the birth, has a mother, however, he/she does not know her identity; the child may then demand that "an envelope with his/her mother's personal data" should be opened, for example, in the proceedings on determining the parenthood. ${ }^{10}$ We may only criticize the meaning of haphazard and non-conceptual bills creating a completely unsatisfactory state undermining pro-family conduct and disrupting the legal consciousness.

If the adoption of a child from the hidden birth is at issue then the situation is more than precarious. We have to start with the fact that a child from the hidden birth has a mother. Due to the international conventions ${ }^{11}$ in 1998 the so-called Great Amendment to the Act on Family was adopted. It is crucial that the natural family of a child enjoys an increased protection and adoption and other forms of an alternative family care are really understood as subsidiary to the care in the natural family. The new legal regulation, after the amendments and pursuant to the New Civil Code, specifies the consent of parents with adoption and the issue of parents' non-interest with the child. As for particularities, we appreciate that mothers may only consent with the adoption of their newborn children after the expiry of the puerperium (cf. Section 68a, AF, Section 821, NCC) and the socalled non-interest is examined by the court in the proceedings on adoptability (cf. Section 68 AF, Section 813 NCC). Therefore we may say that the law protects the mother against impetuous or immature actions while also protecting her underage child or his/her right to life in their natural family. We emphasize that the existing legal regulation as well as the New Civil Code also guarantee full protection for underage parents, especially for underage mothers (cf. Section 67, Para 2 AF, Section 811 NCC). Therefore it is expressly set down that the consent of a parent, or parents, is the basic requirement for adopting a child.

9 We may add that this conception was also taken over by the new Act No 372/2011 Coll. on Health Services which even explicitly mentions preserving the mother's anonymity in Section 37.

10 Towards this, see Hrušáková, M., Králičcková, Z.: Anonymní a utajené mateřství v České republice - utopie nebo realita? [ANONYMOUS AND HIDDEN MOTHERHOOD IN THE CZECH REPUBLIC - UTOPIA OR REALITY?]. Právní rozhledy, 2005, No. 2, p. 53 ff.

11 Cf. the European Convention on the Adoption of Children (see Communication No 132/2000 Coll.) and the Convention on Protection of Children and Cooperation in Respect of Intercountry Adoption (cf. the Communication No 43/2000 Coll.). 
We should note that parents cannot lawfully give up their child. If parents consent with the adoption it is a question whether the registered interested persons will want to adopt their child. The legal bond of the natural parents lasts until other people lawfully become the parents. What is relevant is the legal force of the judgment on adoption. We may add that the Czech legal regulation recognizes only full adoption when the child is fully integrated in the adopting family.

Let us return to the issue of the consent of parents with the adoption of their child. The law distinguishes two types, namely:

(a) direct consent which is given by a parent in the court proceedings on adoption after the expiry of the obligatory preliminary care of the future adoptive parents lasting at least for 3 months (Section 67, AF); the consent with the adoption is also given by an underage parent (cf. Section 67, Para 2, AF);

(b) the so-called blank consent given by a parent generally after the expiry of at least 6 weeks since the birth of the child (cf. Section 68a, AF); then the administrative proceedings on procuring the adoption (matching) by the state may start.

In practice, it often happens that mothers abandon their children after birth, they are not interested in the child anymore and they do not come to give their consent with the adoption. Therefore the law defines the institute of an noninterest with child. Again, two types may be distinguished, namely:

(a) the so-called absolute non-interest lasting for two months after the birth; it is up to the mother to argue and prove in the proceedings on adoptability that she was barred in expressing her non-interest by a serious obstacle (cf. Section 68, Para 1, Sub-Para b, AF);

(b) the so-called qualified non-interest lasting for at least six months anytime during the life of the child; it is up to the mother, or the parents, to argue and prove that they have consistently expressed their interest in the child, especially by visiting the child regularly, by fulfilling their maintenance duty and by showing an effort to regulate their family and social conditions so that they could personally take care of the child in future (cf. Section 68, Para 1, Sub-Para a, AF).

Due to the changes introduced by the Great Amendment to Act on Family (1998) the Civil Procedure Code were amended, too. The so-called proceedings on adoptability of the child were introduced in which the parents' non-interest with the child is examined (cf. Section 180a-180b, Act No 99/1963 Coll., Civil Procedure Code, hereinafter CPC). The participants in the proceedings on adoptability are the parents and the child. If the court founds their non-interest, the child does not become legally free but adoptable. He/she may be put on the list of children eligible for adoption and an administrative body may start pro- 
ceedings on procuring the adoption (matching). If suitable adopting parents are found for the child the interested couple may ask for having the child in the obligatory preliminary care for at least three months. If the care is successful, the interested couple may file a motion with the court for the adoption of the child (cf. Section 181 and the following ones, CPC). Only the interested couple and the child will be participants in the proceedings on adoption of the child. It is important that the child's parents will not be participants in the proceedings on adoption any more as the court had already decided about their non-interest in the proceedings on adoptability of the child.

It is true that the way of the child from the hidden birth to a new family is not a direct or simple one. Nevertheless, if the court decides about adoptability of the child due to the mother's unconcern or her preliminary (blanket) consent (Section 68a, AF), the parents cannot intervene in the proceedings on adoption any more, or extort the adopting parents or otherwise impede their new role.

1.3. As already mentioned in the introduction, since 2005 there has been an increase of the number of private so-called baby-boxes, i.e. the places for putting away unwanted children at the premises of maternity hospitals financed by the Statim foundation. The statistics say that there are already 50 of them and they have "saved" 74 children since $2005 .{ }^{12}$ It is a question whether the so-called babyboxes give the abandon children more chances for adoption. The children from the so called baby-boxes are "without past".

It is crucial that a children from the so-called baby-box have a similar status as a found child even if the former is not legally regulated at all, being it only $a$ private initiative of the Statim foundation. The child from the baby-box has neither mother nor father. Of course, the police have to search for the child's parents as the child has the right - at least theoretically - to know his/her origin. The search is usually fruitless. Nevertheless, in some cases mothers changed their minds about abandoning their child and sought to have the child in their care and to be registered in the book of births.

As for adoption, we may say that the child from the so-called baby-box is "legally free" and therefore "ideal for adoption". However, his/her adoption is often only a theoretical possibility. The persons interested in adoption choose such children only rarely as there is no information about them or their family medical histories. Also, the health state of these children is often problematic as their mothers concealed their pregnancy giving birth in hiding and in unsuitable conditions, i.e. by self-help etc.

However, some experts and the general public have been tolerating the abandoning of unwanted babies in the so-called baby-boxes referring to the idealistic concepts aiming at preventing murders of newborns. ${ }^{13}$ We may only add that in

12 For detail se www.statim.cz ( $15^{\text {th }}$ May 2012).

13 See Zuklínová, M.: Několik poznámek k právním otázkám okolo tzv. baby-schránek [A 
such cases the child cannot be denied the right to bring a status action for determining motherhood if he/she knows who his/her mother is.

\section{SURROGATE MOTHERHOOD: PANDORA'S BOX}

We should first note that the Czech scholarly literature used to condemn experiments of the type of surrogated motherhood referring to common sense and the natural course of things. ${ }^{14}$ During the preparation of the New Civil Code the necessity of regulating surrogate motherhood was not originally discussed at all. The aim of the drafters of the New Civil Code was to follow the traditional principle of the origin of the child from the mother who gave him/her birth and to expressly state that an action of the genetic mother against the mother who gave birth to the child cannot be successful. ${ }^{15}$ Nevertheless, this sentence was not included in the New Civil Code. Instead, there is a short statement saying that the mother of the child is the woman who gave him/her birth (Section 775, NCC). Let us note that it is identical with the existing regulation. It is a pity that the ministerial team turned away from the original aim of the main drafters of the New Civil Code and many co-operators and did not deal with this issue in more detail as it was done in Slovakia. ${ }^{16}$

It is alarming that the New Civil Code uses the term surrogate motherhood, even if in one provision only (cf. Section 804 in fine NCC). It should be noted that the term surrogate motherhood got into the government draft in spite of an express disagreement of many experts as well as the main drafters. The law says quite briefly, that adoption is excluded among relatives in the direct line and siblings and that this does not apply in the case of surrogate motherhood (cf. Section 804 in fine NCC). A provision concerning the so-called surrogate contract has not been included in the New Civil Code nor in any other regulation. As for the medical side of the question, it should have been dealt with in a new Act on Special Health Services. This did not happen, though.

FEW NOTES ON LEGAL ASPECTS OF THE SO-CALLED BABY-BOXES]. Právní rozhledy, 2005, No. 7, p. $250 \mathrm{ff}$.

14 See Haderka, J.: Surogační mateřství [SURROGATE MOTHERHOOD]. Právny obzor, 1986, No 10; Právní ochrana statusu dítěte narozeného z lékařsky navozeného oplodňování: co je a co není právně př́pustné v České republice [LEGAL PROTECTION OF THE STATUS OF THE CHILD BORN DUE TO MEDICALLY INDUCED INSEMINATION: WHAT IS AND WHAT IS NOT LAWFUL IN THE CZECH REPUBLIC]. Správní právo, 1998, No 4; Některé právní problémy reprodukční medicíny [SOME LEGAL PROBLEMS OF REPRODUCTIVE MEDICINE]. Zdravotnictví a právo, 2000, No 2.

15 See Eliáś, K., Zuklínová, M.: Principy a východiska nového kodexu soukromého práva [THE PRINCIPLES AND FOUNDATIONS OF THE NEW CODE OF CIVIL LAW]. Praha: Linde, 2001, p. 167.

16 Cf. Section 83, Act No 36/2005 Z. z. Towards this, see Pavelková, B.: Zákon o rodine. Komentár [THE FAMILY ACT. A COMMENTARY.]. Praha: C. H. Beck, 2001, p. 504 and ff. 
The practice shows that if there is an informal agreement about surrogate motherhood among the relatives, the conception usually takes place in the natural manner. This may sometimes disrupt a fragile family situation. We emphasize that both health acts (the original Act No 20/1966 Coll. as well as the new Act No 373/2011 Coll. on Special Health Services) make it possible to carry out assisted reproduction only with an infertile couple. An artificial insemination of a surrogate mother in a medical institution has thus been out of law and must not be covered by the state health insurance system.

How can intentional parents get an ordered child? If we exclude an exchange of the identity cards of the surrogate mother and the intentional mother, adoption is the only option. As mentioned above, the New Civil Code does not specifically regulate this issue. The mother of the child is then the woman who - even if at an order - gave birth to him/her (cf. Section 50a, AF, Section 775 NCC). After giving birth she may consent with the adoption of her child. We emphasize that due to international conventions and the so-called Great Amendment to the Act on Family (1998) the consent is only valid after the expiry of puerperium. It will be a direct adoption without the necessity of procuring by the state (matching). If the mother who gave birth to the child fails to keep her promise to consent with the adoption and hand the child over to the intended parents the adoption does not take place. If the ordering couple changes their minds refusing to adopt the child their decision must be fully respected.

We hold the view that uncertainty for the surrogate mother as well as the intended mother from the ordering couple constitutes uncertainty for the child from the very beginning. There is a trivialization of the fact that a woman - the surrogate mother - is instrumentalized, that her womb is factually leased for considerable financial amounts and that the human embryo is being degraded to a mere subject-matter of a contract.

\section{RIGHTS OF MOTHER VS. RIGHTS OF CHILD VS. RIGHTS OF FATHER}

As for paternity, the current theory and practice do not often deal with the question whether insisting on the strict law based on traditions protects fatherhood, regardless of being it legal, social or biological. Even less frequently we ask the question whether by insisting on the old conception rights and legally protected interests of the child are not infringed, especially the natural right of the child to know his/her origin. The Czech legal regulation of fatherhood does not basically differ from the conception of earlier European regulations that establish legal assumptions of paternity and that were created at the time when the legitimacy of a child born in wedlock was highly valued and when methods of assisted 
reproduction as well as paternity tests were at their beginnings. The rights of children were taboo as well as human rights in general. ${ }^{17}$

We should note that the so-called Great Amendment to the Act on Family (1998) has strengthened the rights of putative fathers. Following the case law of the European Court of Human Rights concerning Article 8, Convention for the Protection of Human Rights and Fundamental Freedoms, in the case of Keegan vs. Ireland, ${ }^{18}$ the above mentioned Great Amendment to the Act on Family (1998) introduced provisions aiming at strengthening the status of the man who thought himself to be the child's father even against the will of the mother who had given consent to the adoption of the child in the given case. A new provision was added to by the active legitimacy of the putative father to bring an action for determining paternity. ${ }^{19}$ The law then sets forth that a child must not be adopted until the proceedings on determining paternity initiated by the putative father has not been finished (Section 70a, AF).

The New Civil Code brings a number of novelties. Namely, the lengthening of the denying paternity periods in the first assumption benefiting the husband of the mother from the mere six months to six years (cf. Section 785, NCC) and the establishing of the option for the court to excuse someone's missing of these periods (cf. Section 792, NCC) thanks to the finding of the Constitutional Court. ${ }^{20}$ Nevertheless, the conception of assumptions of paternity was not redefined in favor of certainty based on a DNA analysis. The construction of the third assumption of paternity is based on such a state of knowledge when it was not possible to determine positively the father of the child. ${ }^{21}$ It is still based on an intercourse in the so-called critical period (cf. Section 783, AF).

17 Generally, cf. Králićková, Z.: Lidskoprávní dimenze českého rodinného práva [THE HUMAN RIGHTS DIMENSION OF THE CZECH FAMILY LAW]. Brno: Masarykova univerzita, 2009.

18 See the judgment from 25 May 1994, 16/1994/411/ Series A, No 209. A legal wording could be as follows: "An adoption of the child born out of wedlock and against the will of his/her father breaks Article 8, Convention for the Protection of Human Rights and Fundamental Freedoms." See Haderka, J.: Př́ípad Keegan versus Irsko [THE CASE OF KEEGAN VS. IRELAND]. Právní rozhledy, 1995, No. 8, p. 311 ff.

19 Cf. Hrušáková, M. (coll.): Zákon o rodině ... [ACT ON FAMILY ...]. Op.cit., pp. 260 ff.

20 Cf. the finding of the Constitutional Court from the $8^{\text {th }}$ July 2010, Pl ÚS $15 / 09$, published under No 244/2010 Coll.

21 Towards this cf. Frinta, O.: Určování rodičovství (nejen) v návrhu nového OZ [PATERNITY DETERMINATION IN (NOT ONLY) THE DRAFT OF THE NEW CIVIL CODE]. In Šínová, R. (ed.): Olomoucké právnické dny 2008. Olomouc: Univerzita Palackého, 2008, pp. 217 -223, where the author states: "There is a question then whether <the third assumption > should not be understood in another way, and if so, in which one", but I leave considerations according to the designed law aside". In another work of his the author more or less agrees with preserving the existing state of affairs except for the regulation of periods for the so-called critical period, see Frinta, O., Tégl, P.: O návrhu nového občanského zákoníku a jeho kritice (a taky o kontinuitě a diskontinuitě) [TOWARDS THE DRAFT OF THE NEW CIVIL CODE AND A CRITIQUE OF IT (AND ALSO TOWARDS CONTINUITY AND 
Unfortunately, the denying right of the child disappeared from the New Civil Code even if the explanatory note expressly mentions its establishing in connection with the intended subject-matter and principles and the bases of the new code of private law. ${ }^{22}$ By preserving the legal situation based on assumptions, the lawgiver does not give the child a chance to realize his/her interests in finding out his/her origin and bringing his/her biological reality in line with the legal state. We may imagine a situation when the interests of the mother, the father and the child are mutually in conflict and it is necessary to look for a solution. The European Court for Human Rights held in the case Paulik vs. Slovakia that "when denying paternity the lack of a procedure for bringing the legal position into line with the biological reality flew in the face of the wishes of those concerned in the given case and did not in fact benefit anyone." ${ }^{23}$ We hold the view that the fact that the child cannot directly seek denial of paternity impedes him/her to establish a legal relationship with the man who conceived him/her and who would fulfill his role of social father if he had knowledge of his paternity. The assumptions or the lapse periods for their denial protect primarily mothers who usually know best who the father of their child is. The interests of the child may be in conflict with the interests of the mother. ${ }^{24}$ It cannot be said that by protecting mothers the law protects their children at the same time. ${ }^{25}$

\section{CHILD V. DOMESTIC VIOLENCE}

As already mentioned, an underage child cannot be protected against the divorce of his/her parents. Both the experts and the public ask the question how

DISCONTINUITY)]. Právní rozhledy, 2009, No 14, p. 498.

22 Cf. Eliáš, K., Zuklínová, M.: Principy a východiska nového kodexu soukromého práva [THE PRINCIPLES AND FOUNDATIONS OF THE NEW CIVIL CODE]. Op. cit., p. 168 , where the authors state that the new legal regulation will be added to by "the right of a major child to deny paternity (resulting from the right a person to know his/her biological origin)."

23 Cf. the judgment from $1^{\text {st }}$ October 2006, complaint No. 10699/05 in the issue of the right to have private and family life respected, the prohibition of discrimination and the right to peacefully enjoy property. Towards this cf. the reaction of the Slovak lawgiver in the issue of a new trial due to the Strasbourg case law (see Section 228, Para 1, Sub-Para d), Slovak Civil Procedure Code].

24 Towards this cf. the statement of the Ombudsman as a collision custodian of the child included in the Finding mentioned under note No 19 above, where he does not recommend abolishing the period at issue referring to - among others - the right of the mother to have her honor, privacy and good reputation protected (sic!).

25 We fully agree with the finding of the Constitutional Court in the case mentioned above that "In the opinion of the bench of the Constitutional Court, the unconstitutionality of Section 57, Para 1, Family Act, consists primarily in the imbalance of the basic rights and interests of the child's father, whose paternity was determined on the basis of the first assumption of paternity, those of the child and those of his/her mother. The unconstitutionality of the above mentioned provision may also be supported by the conflict with the child's own interests." See also Králićcková, Z.: Ochrana slabší strany v rodinném právu [PROTECTION OF THE WEAKER PARTY IN FAMILY LAW]. Právník, 2011, No. 4, pp. 362 ff. 
to protect a child against domestic violence which often appears in connection with the breakdown of the marriage.

It should be noted that by the police banishment for 10 days (Section 44, Act No 273/2008 Coll. on Police of the Czech Republic) or the court banishment for 1 month (see Section 76b, CPC) of a violent person from the household the problems caused by domestic violence cannot be complexly solved. ${ }^{26}$

Due to the new provision of Section 25, AF, established by the so-called Great Amendment to the Act on Family (1998), a marriage cannot be divorced until a judgment on the post-divorce care of the minors (exclusive, joint or alternative), the maintenance and the contact rights is made. ${ }^{27}$ The court deciding about the post-divorce care of the minors has usually no other choice than to regulate the situation of the child authoritatively if an agreement of the parents cannot be approved. The court divorcing the marriage more or less takes into account the decision on the post-divorce regulation of the relation of the parents to the minors. ${ }^{28}$

If a family is endangered by domestic violence the necessity to regulate the relationship to the minors before the divorce itself may make the situation of the endangered persons much worse. Of course, it often depends more on the legal reasons of housing and other property aspects of the marital co-existence than on the termination of the marital status by the court.

The New Civil Code follows the so-called Great Amendment to the Act on Family (1998) and the intended subject-matter is still based on the so-called qualified breakdown of marriage with the condition that if the married couple has children, the judgment on divorce must be preceded by the decision on the relation to the minors for the post-divorce period (cf. Section 755, Para 3, NCC).

We appreciate the fact that the new legal regulation considers the phenomenon of domestic violence establishing the option of the court to restrict or exclude the right of the violent partner or the ex-partner to live in the house or the flat regardless of the legal reason for his dwelling there (cf. Sections 751-753, NCC, A special provision against domestic violence, cf. also Section 762, Para 2, NCC,

26 For details see Králíčková, Z., Žatecká, E., Dávid, R., Kornel, M.: Právo proti domácímu násilí [LAW AGAINST DOMESTIC VIOLENCE]. Praha: C. H. Beck, 2011.

27 We emphasize that parental responsibility lies with both parents always according to the existing law (cf. Section 31 and further, AF).

28 We should note that the so-called Great Amendment to the Family Act (1998) established an option of divorce pursuant to Section $24 \mathrm{a}, \mathrm{AF}$, without ascertaining the so-called qualified breakdown of marriage or its reasons. However, not every couple is able to reach an agreement on the divorce, on the post-divorce arrangement of relationships to the minors, on the division of the community property and on the arrangement of the use of the family dwelling. Not always the reasons are only subjective. Sometimes the option of the so-called agreed divorce is made impossible by objective facts, such as continuing domestic violence in the broadest sense of the word. 
in connection with the maintenance of the ex-spouse; in context of inheritance law cf. also Section 1482, NCC, and also Section 3021, NCC, included in the transitory and final regulations). However, it is a period of maximum six months even if with the option of repeated prolongation (cf. Section 752, NCC). It is surprising that the lawgiver chose a shorter period than that of the so-called court banishment which may be ordered for up to one year (cf. Section 76b, CPC). This procedural institute appears then more favorable. It should be noted that both institutes may be freely combined.

Unfortunately, the New Civil Code does not say anything about minors endangered by domestic violence not even in connection with divorce or postdivorce arrangements of relations to minors, or in connection with the regulation of the exercise of parental responsibility after divorce or during de facto separation of the parents. The experts hold the view that the situation of minors endangered by domestic violence must not remain without regulation regardless of the factual separation of the parents of the child due to the spouse's fleeing from the family dwelling because of the violent spouse, or due to banishing, restricting or prohibiting to use the family dwelling, or due to divorce. The situation is more than difficult and it cannot be said that if a legal regulation protects the parent endangered by domestic violence it also protects the child even if he/ she frequently witnessed physical or psychical attacks. ${ }^{29}$

There is a problem primarily that the court is not expressly given a duty ex offo to regulate the situation of a minor especially if one of the parents is banished from the family dwelling (by police or court) or if his/her right to live in the family dwelling is temporarily restricted or abolished. As the issue is not regulated we may only state that:

- the banished parent, or the parent prohibited from meeting and contacting the other parent of the child, is only factually restricted in the exercise of parental responsibility, especially in the personal care of the child, but he/she remains a legal representative of the child with the right to decide about substantive issues concerning the child, and if not decided by the court otherwise, with the right to contact personally (or in other ways) the child; it is necessary for the banished parent to contact a respective intervention center and an authority in charge of social-legal protection of children and to ask for mediating personal or another contact with the child;

- therefore it is necessary to distinguish whether the parent has been banished because of a minor regardless of the minor being a direct or indirect victim (witness) or for other reasons;

29 The author is updating her ideas published earlier, see e.g. Králičková, Z.: Dítě ohrožené CAN a domácím násilím [THE CHILD ENDANGERED BY CAN AND DOMESTIC VIOLENCE]. Právní rozhledy, No 11, pp. 381 - 389. 
- if domestic violence is connected with the child it is necessary to consider whether a parent should be deprived of parental responsibility (Section 44, Para 3, AF) or restricted in or prohibited from personal or another contact with the child (Section 27, Para 3, AF).

As for the New Civil Code, we appreciate the fact that it makes possible to regulate contact on the so-called neutral ground, or to set conditions or the circle of persons who are or are not allowed to be present (cf. Section 888, NCC). ${ }^{30}$ We appreciate the fact that in harmony with the trends ${ }^{31}$ the New Civil Code establishes an explicit duty for the court to deal with the right to contact with the child of the parent whom it restricts in parental responsibility (cf. Section 872, NCC). If the parent is deprived of parental responsibility he/she does not have ex lege right to contact with the child unless the court decided not to deprive the parent of contact rights because of the interests of the child (cf. Section 872, NCC).

\section{CONCLUSION}

It has been hinted above that a minor often gets endangered due to an objective unfavorable situation but also due to a pathological conduct of his/her parents.

As for the legalizing of hidden births or the introducing of surrogate motherhood into the legal order of the Czech Republic we may state that both institutes give mothers rights regardless of their children's rights and legally protected interests. Fathers' rights are often omitted completely. The fact that the situation of minors endangered by domestic violence is not explicitly regulated, especially in connection with divorce or (forced) separation of their parents, brings about a number of problems in practice. This benefits no one - especially the endangered minors.

30 The Section 888, NCC, sets forth: The child who is in care of only one parent has the right to contact with the other parent to the extent which is in the interests of the child, and similarly, the other has the right to contact with the child unless the court restricts or prohibits such a contact; the court may also set conditions of contact, especially the place where it should take place as well as the persons that are allowed or are not allowed to be present. The parent who has the child in his/her care is obliged to prepare the child properly for the contact with the other parent, to enable properly the child's contact with the other parent and to cooperate with the other parent to the necessary extent during his/her exercise of the right to personal contact with the child.

31 See e.g. United Nations. Department of Economic and Social Affairs. Division for the Advancement of Women: Handbook for Legislation on Violence against Women. New York: United Nations, 2010; Jackson, N. A. (ed.): Encyclopedia of Domestic Violence. London: Routledge, 2007. 
ICLR, 2012, Vol. 12, No. 2.

\section{Attachment No I.}

Extra marital births 1950-2011

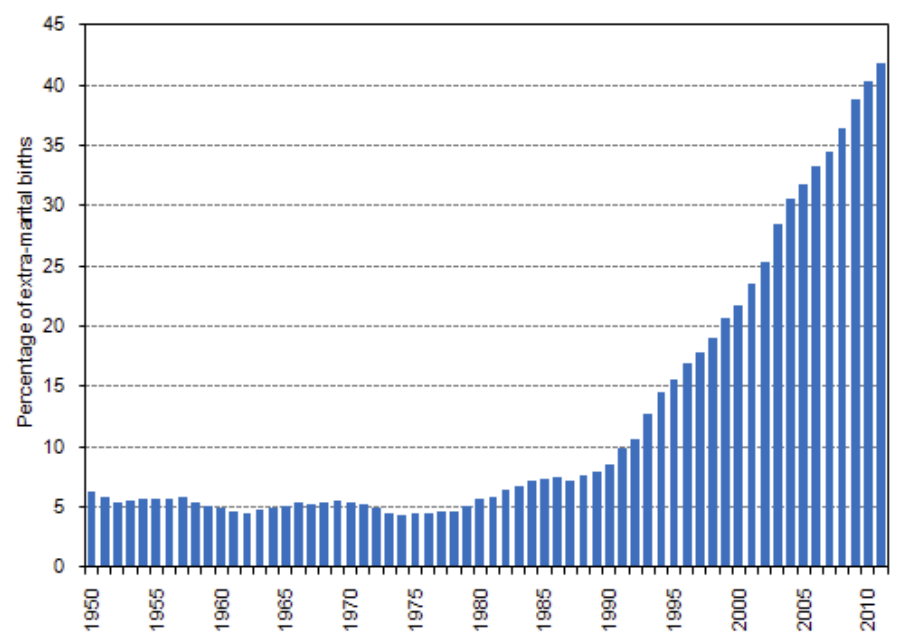

Attachment No. II

Marriages and divorces 1950-2011

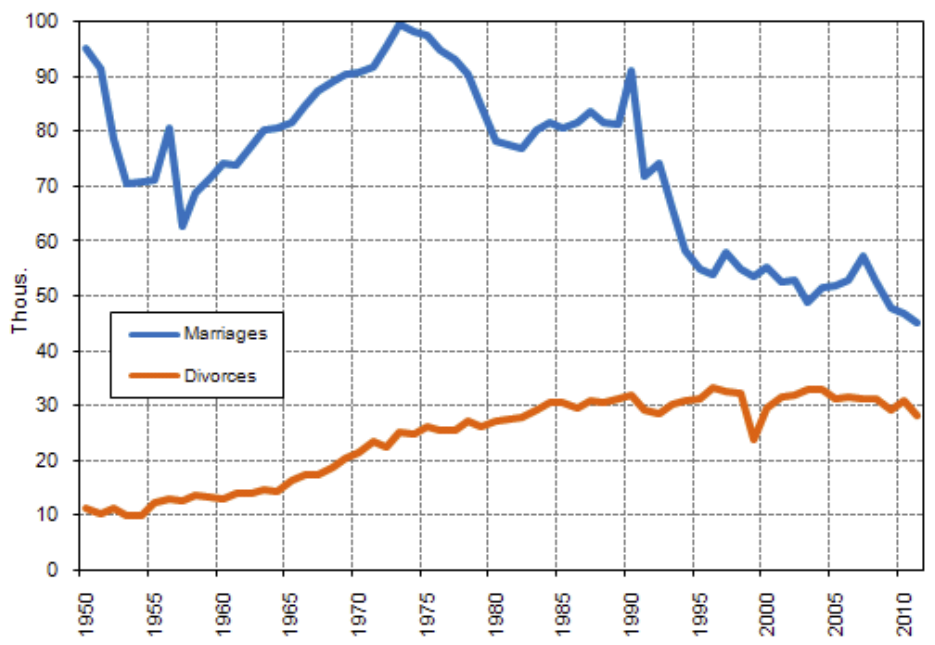

